tion between the chamberlets is clearly seen, that is, connexions with adjacent chamberlets on either side in preceding and succeeding whorls, but none with neighbours of the same whorl ; and the canal system full of protoplasm is also visible in the thick septa of the shell.

This note is published only partly in order to record the expected multinuclear nature of a microspheric Cycloclypeus. Our too fragmentary knowledge of this surviving protozoan prehistoric monster will no doubt some day be amplified, and a great part of the object in writing this letter lics in the hope that it may help to speed that day.

Margaret W. Jepps

Department of Zoology,

University, Glasgow.

Dec. 18

${ }^{3}$ lister, J. J., H'hil. Trans., B, 186, 437 (1895).

${ }^{2}$ Lister, J. J., "Foraminifera", in "A Treatise on Zoology", edit. by E. Ray Iankester, Pt. 1, 2 (London).

\section{Genetic and Morphological Evidence for Subspecific Differences between Naples and Plymouth Populations of Ophryotrocha puerilis}

INDIVIDUALS of Ophryotrocha until now classified as $O$. puerilis and collected in the Bay of Naples and at Plymouth breed normally, if kept in Naples water, under conditions described elsewhere ${ }^{1}$. 'The Naples and the Plymouth populations are unquestionably closely related and have the same chromosome number $(2 n=8)$. However, cross-breeding between a Naples individual and a Plymouth individual has constantly resulted in embryos which degenerated at an early stage and were eaten by their parents.

$O$. puerilis is known as a protandrous hermaphrodite $^{2}$. Comparative studies of the first appearance and development of eggs in numerous individuals kept under identical conditions at a temperature between $17^{\circ}$ and $18^{\circ} \mathrm{C}$. gave the following results : (a) Small oocytes first appear in isolated Naples individuals at a mean size of eighteen chrtigerous segments, whereas in isolated Plymouth individuals they appear at a mean size of twenty chrtigerous segments (see graph). (b) The complete maturation of oocytes takes place in all the isolated Naples individuals, while the maturation of oocytes is seldom reached in isolated Plymouth individuals. (c) The Plymouth individuals in the female phase appear to reverse into the male phase more rapidly than the Naples individuals under the action of environmental factors ${ }^{3}$. 'This result may be partially explained by observations $(a)$ and $(b)$.

A careful morphological examination of the Naples and Plymouth specimens-both alive and preservedrevealed to one of us no substantial differences other than in the two parts of the mandibles (nomenclature from McIntosh ${ }^{4}$ ). The crenate apical portion of each of these pieces is supported by a plate which is comparatively large in the Plymouth individuals, but is much reduced or even absent in the Naples individuals. The wing-like border occurring close behind the anterior region is also rather elongated in the Plymouth strains, more triangular and broader in the Naples strains (see graph).

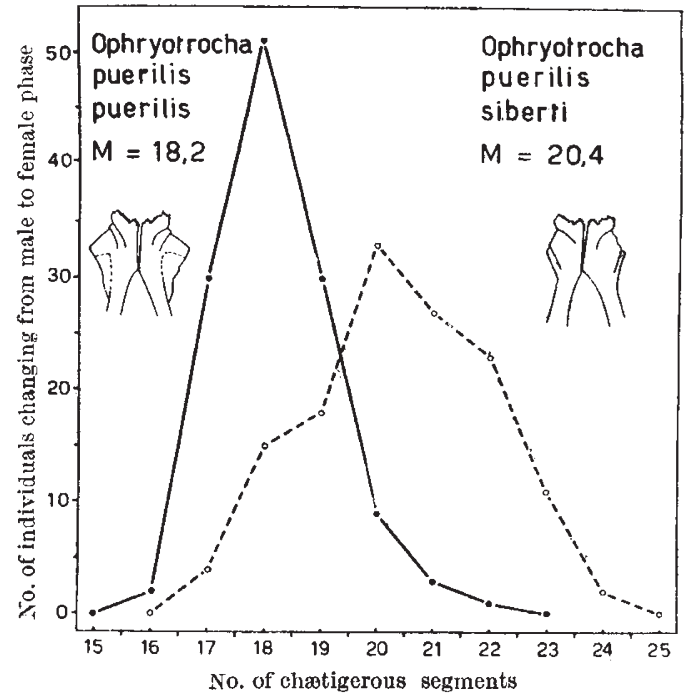

Ophryotrocha puerilis puerilis (continuous line) and 0. puerilis siberti (broken line). Ieft $:$ mandibles of $O$. puerilis puerilis; right: mandibles of $O$. puerilis siberti

In a survey of the available literature on the Mediterranean and Atlantic Ophryotrocha, no detailed observations have been found on the struature of the mandibles; but some information has been collected by the examination of some carefully drawn outlines of the armature of the proboscis. It appears, for example, that the Ophryotrocha from Whitstable oyster beds described by McIntosh ${ }^{5}$ under the name Staurocephalus siberti almost certainly corresponds to the Plymouth Ophryotrocha now being cultivated in the Naples Zoological Station.

From a strictly genetic point of view, the Ophryotrocha from Plymouth now studied should be named as a separate species from the Naples Ophryotrocha which is the true puerilis, since Claparede and Mecznikow ${ }^{6}$ collected their specimens in the Bay of Naples. However, a number of considerations, which will be discussed elsewhere, induce us to adopt the trinomial nomenclature (Ophryotrocha puerilis puerilis Clap. and Meczn. from the Bay of Naples, and $O$. puerilis siberti McInt. from Whitstable and Plymouth) in order to stress the close relationship between the two populations.

A more detailed paper on this subject will be submitted elsewhere.

Our thanks are due to Mr. F. S. Russell, and to the staff of the Marine Biological Laboratory, Plymouth, for the many courtesies extended to us.

Stazione Zoologica di Napoli.

\section{GuIdo BACCI}

\section{Marcello la Greca}

Istituto di Zoologia,

Universitá di Napoli.

$$
\text { Feb. } 15 .
$$

1 Bacei, G., Exper., 7, 222 (1951) ; Boll. Soc. Ital. Biol. Sper., 27, 778 (1951).

'Braem, F., Z. wiss. Zool., 57, 187 (1893). Korschelt, E., Z. wiss. Zool., 5̈7, 224 (1893).

${ }^{3}$ Bacci, G., Boll. Soc. Ital. Biol. Sper., 28, 1296 (1952).

"MeIntosh, W. C., "British Marine Annelids", 2, 364 (1908).

'McIntosh, w. C., Ann. Mag. Nat. Hist., (5), 16, 480 (1885).

- Clapardde, E., and Mecznikow, E., Z. wiss. Zool., 19, 163 (1869). 